\title{
SELF-PRESENTATION OF POLISH FOOTBALL MANAGERS ON LINKEDIN
}

\author{
Aleksandra Kuzior ${ }^{1}$
}

\begin{abstract}
Although LinkedIn is the world's largest professional networking site, the research concerning self-presentation on the platform is limited and fragmented. The main goal of the study was to explore the self-presentation of Polish football managers on Linkedln in four dimensions: completeness and attractiveness of the profile, network-embeddedness, and activity. Using quantitative content analysis of managers' profiles ( $N=319)$, the research shows that the managers exploit the potential of LinkedIn to build their personal professional brand only in a very limited and mostly static way. In addition, the self-presentation in Linkedln is the best among managers working in Polish Football Association, improves with the length of professional experience, and shows only slight differences between women and men.
\end{abstract}

Key words: LinkedIn, sport management, self-presentation, personal brand

\section{INTRODUCTION}

The birth of social media created a new space for the development of personal image for every Internet user (Kim, Kim, \& Nam, 2014). Soon, next to platforms meant primarily for users' private life, such as Facebook, YouTube, or Tinder, the emergence of platforms helping members find a job or a business contact and create a professional personal brand. Among them was seen, Linkedln is the biggest one.

Developing an online professional personal brand is a challenging task. Its image should be convincing and credible for strangers in a targeted industry. Therefore, it should give proof of required competencies for a desired job or of appropriate experience to become a business partner. At last, but not least, it should help a user stand out among their peers (Evans, 2014).

The advantage of Linkedln over other portals used in a job search is its transparency of information supplied by users, popularity among highly skilled personnel, and the presence of people currently not looking for a job (Cooper \&Naatus, 2016; Hempel, 2010). The latter feature is especially important for recruiters looking for highly specialized employees and for people interested in finding or maintaining business contacts.

LinkedIn, however, does not compete only with smaller business platforms, but also with bigger social media as Facebook or Twitter. For that reason, it develops various features to attract and keep recruiters and business oriented users (e.g. functions of Premium profiles) along with tools supporting content sharing and enhancing user en- 
gagement (Cooper \&Naatus, 2016).

The dominance of Facebook or Twitter is also seen in scientific research in social media. Nevertheless, the online self-presentation on LinkedIn is also studied, even if in a fragmented and limited way. The dominant perspective in this area is the usefulness of the profiles in the recruitment process (Zide et al., 2014, Geyik et al., 2018). Corresponding themes are those of the credibility of the profiles (van de Ven, Bogaert, Serlie, Brandt, \&Denissen, 2017), or intercultural differences (Rui\&Stefanone, 2013). There are also few studies on the self-presentation of organizations in Linkedln (Banerji\& Reimer, 2019; Lops, de Gemmis, Semeraro, Narducci, \&Musto, 2011; Sievers et al., 2015; Utz, 2016; Saint-Jacques, Varshney, Simpson, \&Xu, 2019). The few analysis focused on personal self-presentation (e.g., Duffy, Pruchniewska, \&Scolere, 2017; Rui\&Stefanone, 2013; Tifferet\&Vilnai-Yavetz, 2018, Zide et al., 2014) concern only limited dimensions of the concept on the one hand, and of LinkedIn potential, on the other hand.

Therefore, the goal of the presented research was a multidimensional exploration of the self-presentation on Linkedln. As the research sample sport managers active in Polish football were chosen. This choice is based on several reasons: 1) even though the profession of sport managers is gaining importance in Europe (which is seen in progressing professionalization and commercialization of many sports, and in popularity of sport management master programs), there are very limited studies of the sport business professionals, 2) in Poland sport management is under a strong pressure to professionalise, which implies new challenges for people in charge of the industry, 3) the only study of Polish managers' activity on Linkedln concerns export managers (Deszczyński, 2017).

The contribution of the study to the research is then trifold. Firstly, the study helps to understand the social media behaviour of a professional group that is largely under-researched. Secondly, it explores the relations between different dimensions of a self-presentation in a business social network. Thirdly, it proposes a set of indicators to measure these dimensions (completeness and attractiveness of the profile, network embeddedness, activity).

\section{BACKGROUND}

\section{Linkedln profile}

Linkedin.com is the largest professional website in the world. The website gathers 610 million users from over 200 countries. It was created on May 5, 2003. Since 2016 it is part of Microsoft (about.linkedin.com 2019). According to the vision and mission of the website, the platform helps find a job for people who are looking for it, and brings together specialists who want to broaden their professional competences and knowledge, exchange ideas, search for new development opportunities (Case et al. 2013).

The portal gives a chance to create a profile containing personal data, career path, education, accomplishments, and interests, but also allows a user to make contact with other people, participate in industry forums, subscribe to influencers profiles, companies, and groups (Anabo and Albizuri 2017). Upon registering, users are invited to fill in a structured template, which will become their official profile. Users are encouraged to complete as many parts as possible (they are informed of the degree of completeness of their virtual resume). Achieving $100 \%$ positions a profile higher in LinkedIn search engine and shows information about its owner on the pages of other members more often. Creating an account on LinkedIn and its corresponding public profile should be treated as a realization of a self-presentation strategy with professional goals.

\section{Self-presentation in social media}

The academic literature considers managing self-presentation in online communi- 
ties as an integral part of private and professional life (Chiang and Suen 2015). A successful self-presentation involves an adaptation of a user's image to a model generally accepted by the environment. It should be consistent with the occupied social position and created in such a way that a received image is concordant with expectations of recipients (Rui and Stefanone 2013). As acceptance in online communities is influenced also by extensive self-presentation, usually, the willingness to provide personal information in the profiles is high (Schwämmlein and Wodzicki 2012). The completeness of the information is especially important in the business social networks, as it may be a decisive factor of a recruiter's consideration (Zide, Elman, and Shahani-Denning 2014). Still, the effective self-presentation requires not only sufficient information but also its right selection. The selection of information displayed allows members to influence the reaction of the audience, as well as the relationships that will eventually be established.

A well-created profile has a positive effect on the user's relations with other members (recruiters or potential business partners) and positively affects positioning in the search process. The opposite is also true. There are no barriers to creating a non-professional Linkedln profile. This is the case for example of profiles which are poor in information about professional experience and education, but rich in skills and interests (Zide, Elman, and Shahani-Denning 2014).

Professional self-presentation treated as a process of managing information about self consists not only of a display of achievements and experiences, neither in the real or virtual world. It includes also a disclosure of personal opinions, exchanging comments, building long-lasting relations with other people active in similar professions, following influencers, presenting ways of spending free time.

Therefore, a successful creation of the personal professional brand in social networks involves communication with others, openness to new ideas (Toma and Hancock 2010). Consequent and consistent activities, such as publishing posts presenting personal positions or views, build loyalty among observers. It is important to pay attention to the authenticity of the communication, as users sign with their real name. Therefore, the information provided should be verifiable and coherent with other Internet sources, private social media included (if they are signed with the user's real name). This rule may be seen as a barrier to evoke public reactions compared to anonymous participation in social media, when private and informal information may serve as clickbait (Cho 2010). The business image in social media is also linked to the real world of work - excellence in the job brings about recommendations in a virtual resume providing valuable proofs of professionalism (Guillory \& Hancock, 2012, Niedźwiedziński, Klepacz, Szymańska, \& M, 2016, J. R. Rui, 2018).

In business social networks, unlike in many other social networks, expanding the network of contacts is not aimed primarily at transferring personal relationships to the virtual space and maintaining them (Papacharissi 2009). Instead, it is used to build valuable business relationships and manage them in order to build and develop a career (Conlon et al. 2017). Moreover, building long-lasting ties with people who are active and respected in similar professions provides information to others that the self-presentation and self-development is a mindful strategy. On the other hand, in business and other networks, maintaining contact with people who do not care about their self-presentation may harm the image of the individual (Morgan 2011).

\section{METHOD}

\section{Research design}

The research included four phases: 1) generating data from Linkedln users' profiles, 2) construction of four indexes describing the use of Linkedln by sample users, 3) exploratory analysis of obtained indexes, 4) correlation analysis of indexes with some 
variables describing the sample.

\section{Data generation}

In this research, the quantitative method of content analysis of LinkedIn users' profiles was applied. The first step was to prepare a control card which was based on a literature review and author's study of LinkedIn potential. The second step was to find managers working in Polish football having Linkedln profiles, which was done using the Recruiter Lite tool. The search for the profiles was done according to the place of employment and concerned the football clubs playing in Ekstraklasa, I, II, III and IV leagues, as well as Polish Football Association (PZN), regional football associations (OPZN, WPZN), Ekstraklasa company, and football academies. Information about the football clubs competing in each league was taken from the website of PZPN, while data about football academies and other associations were found on Linkedln by entering into its search engine such keywords as: 'football school', 'football academy'. Employees from clubs and organizations who work in administrative departments and employees of the sports departments who perform managerial functions were selected (excluding i. e. football players, coaches, scouts, physiotherapists, people responsible for the grass, protection or lighting). This way 319 LinkedIn users profiles were selected in July 2018. In the next step, the information found in the profiles was coded in a spreadsheet, resulting in ratio, interval, and nominal data used in the subsequent analysis.

\section{Construction of indexes}

Based on the collected data four indexes were created. They describe different aspects of Linkedln utilization to create a personal professional image: completeness, activity, network embeddedness, attractiveness. Value of indexes for each Linkedln user is a quotient of the sum of scores in each component and the number of these components. Index components themselves are constructed in a similar way - they are an average of normalized elementary variables making up the components. All normalization is realized by dividing the observed score by the maximum observable score, resulting in data ranging from 0 to 1 .

\section{The completeness index}

The index contains six components. The data in this index were coded as 1 (0) if the part of the profile was (wasn't) entered or personalized by the user. The first component is 'the completeness of the user card'. It takes into account a profile photo, background photo, and summary. The second component, 'the completeness of professional experience' is formed of a place of work, position, and range of working time in that place. The same is with 'the completeness of education' component. In Linkedln, the area below the place of work or education is an opportunity to publish a description of the functions performed. This is the fourth component of the index. The fifth part is 'the completeness of additional work experience'. This section contains honors and awards, publications, projects, organizations, volunteer experience and causes, courses. The last component of the index is 'the completeness of skills' and contains information, whether the user published any skills on their profile (1) or not (0).

\section{The activity index}

To create the index monthly averages of the number of articles, likes, shares, own posts, and comments of each user were calculated. The data were subsequently normalized to the range of $0-1$.

\section{The network embeddedness index}


The network embeddedness is made of four components. The first of them is the network size of the user and represents the number of Linkedln members the owner was connected to. On the platform, larger network sizes are marked as 500+. In such cases, the registered score was 500 (subsequently normalized to 1). The second component of the index is a normalized number of approvals of the user's skills. The third one is a normalized number of recommendations received and given by the user. The last component of the index considers interests displayed in the lowest part of the profile. It is an average of the normalized number of influencers, companies, schools, and groups that a Linkedln member is following.

\section{The attractiveness index}

The index is made of six components. The first one concerns the information from the user's card, named 'more contact info'. It consists of an average of elementary variables registering as $1(0)$ presence (absence) of e-mail, telephone number, and links to Facebook, Twitter or user's website. A second component is a normalized number of files attached to the profile. Users can add them in many parts of the profile, for example in the summary or in the work experience areas. The third component is the author's evaluation of the professional summary (considering Linkedln guidelines which suggest to include in this area information about career path development, career future plans, and business interests). The fourth component registers presence (absence) of a personalized link to Linkedln account as $1(0)$. The fifth component is the author's general assessment of the profile in terms of professional business interest (profile scores 1 if it can be seen that the user is interested in the sport industry and actively develops interests in this area). The final component takes value 1 if the profile is free of language errors, 0 otherwise.

\section{Analysis of indexes}

The analysis was done in two steps - first, exploratory analysis allowed to determine principal statistical characteristics of the indexes and characterize some particular cases, than further analysis determined connections between indexes and some variables describing the sample. As the indexes don't show the normal distribution, the non-parametric test was used in this part of the research. The analysis was carried out in Statistica 13.1.

\section{RESULTS}

In the first step, exploratory data analysis of four constructed indexes was undertaken. Regarding completeness (Figure 1), it may be concluded that even though none of the Linkedln users had entirely complete information in their profile, almost $3 / 4$ of the respondents scored more than 0.5 , with the median score of 0.6 . In fact, the completeness scores are the best among all four indexes. Second comes attractiveness (with the median of 0.20 ), followed by network embeddedness (median= 0.09), and activity (median $=0.00$ ). Especially two latter indexes show important positive skewness, with the majority of the scores grouped in the lowest quantiles, indicating the dominance of no or scare social embeddedness and activity among managers. Unsurprisingly, the results of tests shown in Figure 1 clearly reject the hypothesis of the normal distribution of all the indexes. 
Figure 1. Indexes - main statistics
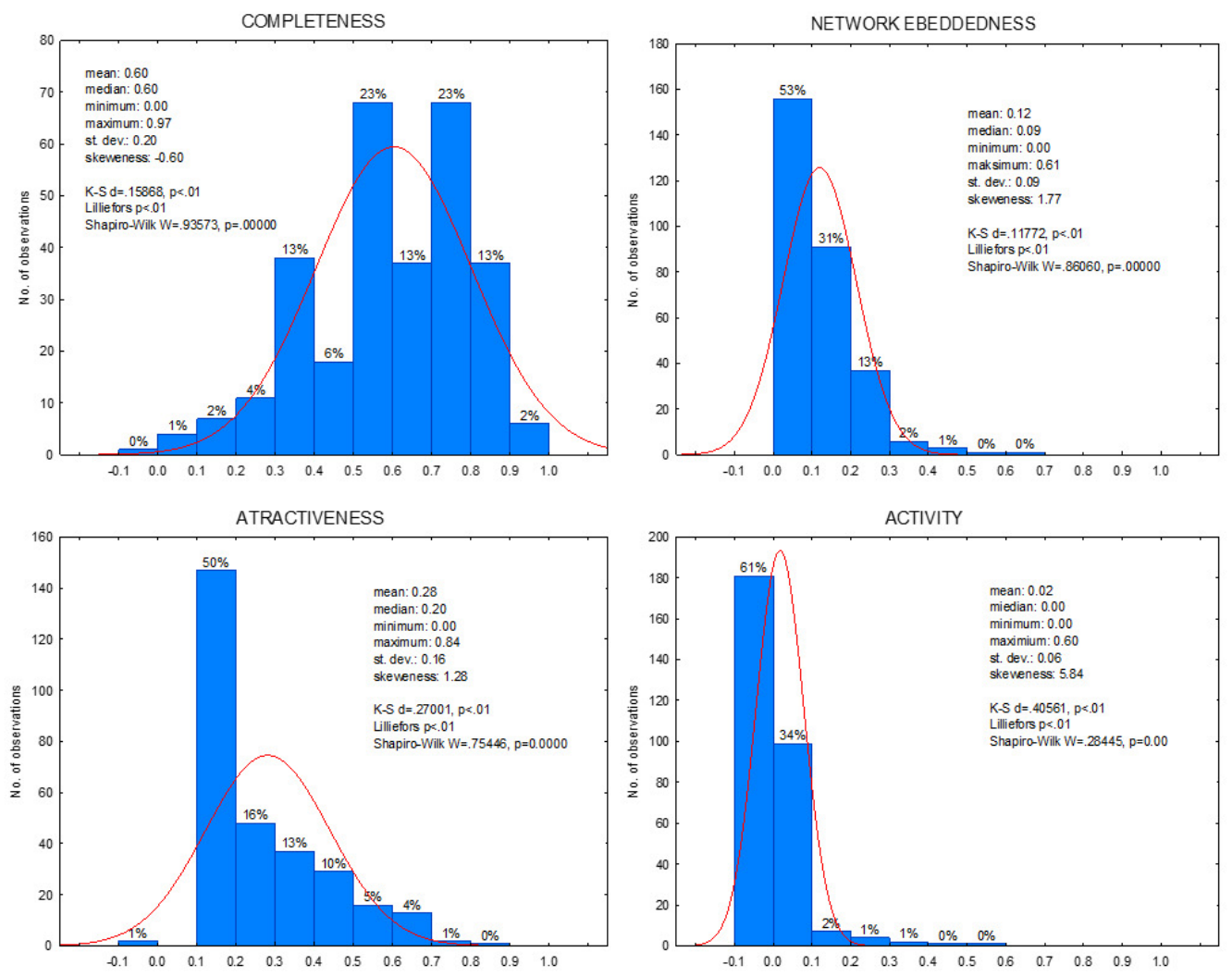

Source: author's own research

As shown in Table 1, there is a positive and statistically significant correlation between all indexes. The strongest association is observed between the attractiveness and completeness indexes (0.57), while a slightly lower correlation is registered between network embeddedness and completeness (0.49), network embeddedness and activity (0.44). Attractiveness and activity indexes, on the other hand, show the weakest relationship.

Table 1. Indexes - correlation (Spearman's rho)

\begin{tabular}{|c|c|c|c|c|}
\hline INDEX & COMPLETNESS & ACTIVITY & $\begin{array}{c}\text { NETWORK } \\
\text { EMBEDDEDNESS }\end{array}$ & ATRACTIVENESS \\
\hline COMPLETNESS & 1.00 & $0.37^{\star}$ & $0.49^{\star}$ & $0.57^{\star}$ \\
\hline ACTIVITY & $0.37^{\star}$ & $1.00^{\star}$ & $0.44^{\star}$ & $0.32^{\star}$ \\
\hline $\begin{array}{c}\text { NETWORK } \\
\text { EMBEDDEDNESS }\end{array}$ & $0.49^{\star}$ & $0.44^{\star}$ & 1.00 & $0.35^{\star}$ \\
\hline ATRACTIVENESS & $0.57^{\star}$ & $0.32^{\star}$ & $0.35^{\star}$ & 1.00 \\
\hline
\end{tabular}

Source: author's own research

Further analysis of the scatter plots (Figure 2) allows identification of some particular cases that cannot be seen in the table above. Notably, one may notice that observations with the highest activity are also characterized by high completeness and network embeddedness, but rather medium attractiveness. On the other hand, extreme cases of the highest attractiveness show also the highest level of completeness, but rather lower levels of activity and network embeddedness. 
Figure 2. Indexes - scatter plots

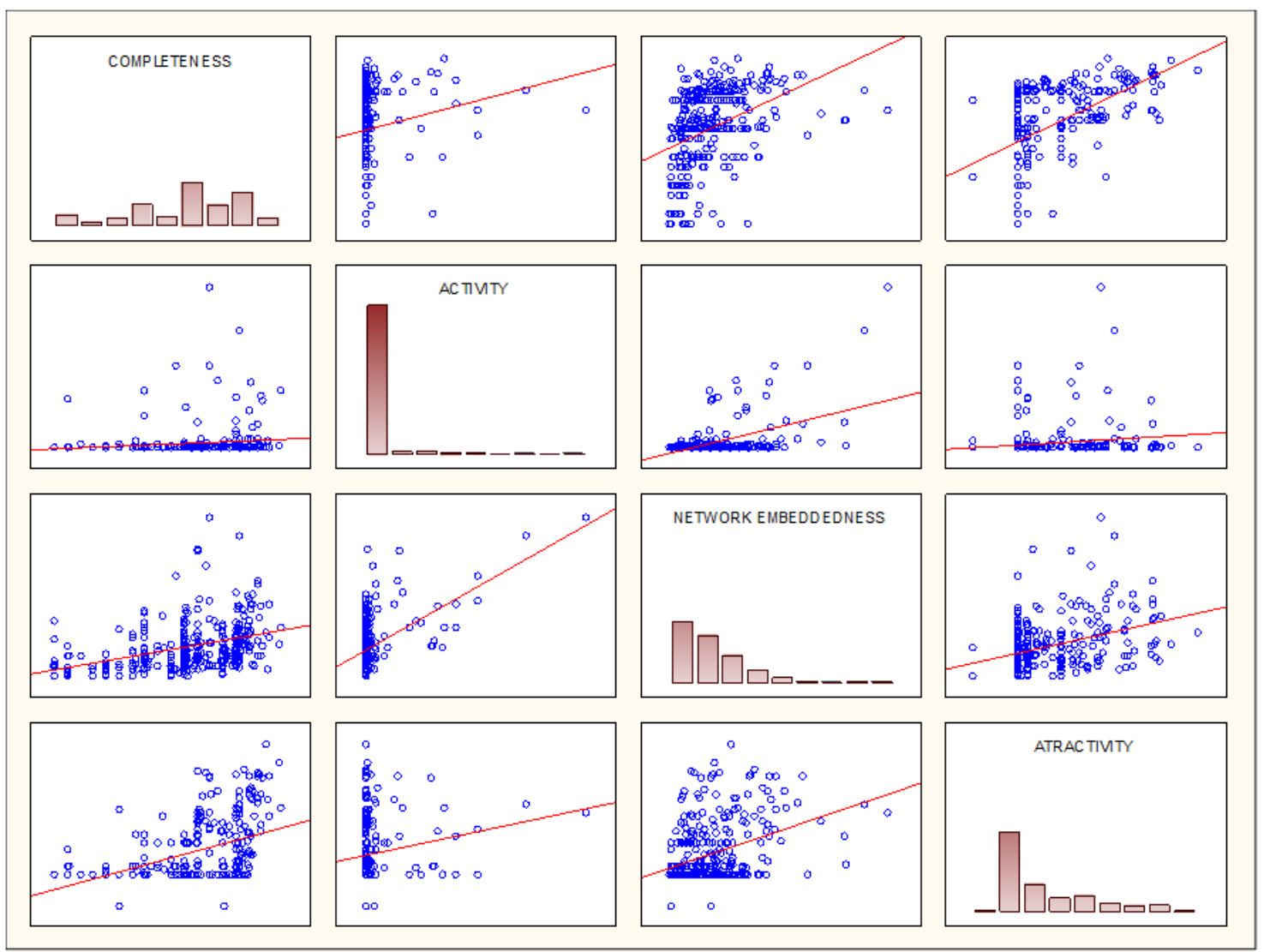

Source: author's own research

The next step of this study was to determine a relation between indexes and some variables describing the sample: gender, organization, position, length of work experience.

Table 2 illustrates the correlation of indexes with the user's gender. The result of Mann-Whitney $U$ tests shows that only network embeddedness may differentiate women and men (and only at $10 \%$ significance level), with men being slightly more network embedded.

Table 2. Indexes - correlation with gender

\begin{tabular}{|c|c|c|c|c|}
\hline INDEX & TOTAL & WOMEN & MEN & $\begin{array}{c}\text { U MANN - } \\
\text { WHITNEY U TEST }\end{array}$ \\
\hline COMPLETNESS & 0.56 & 0.53 & 0.57 & $\mathrm{p}=0.26$ \\
\hline ACTIVITY & 0.02 & 0.02 & 0.02 & $\mathrm{p}=0.14$ \\
\hline $\begin{array}{c}\text { NETWORK } \\
\text { EMBEDDEDNESS }\end{array}$ & 0.11 & 0.10 & 0.12 & $\mathrm{p}=0.08$ \\
\hline ATRACTIVENESS & 0.27 & 0.25 & 0.28 & $\mathrm{p}=0.12$ \\
\hline
\end{tabular}

Source: author's own research

Table 3 presents the relationships between indexes and workplaces. The results of ANOVA Kruskal-Wallis tests show, that at $5 \%$ significance level, the level of completeness, activity, and network embeddedness indexes may be differentiated by the organization in which the user is employed. In particular, managers who work in Polish Football Association (PZPN) have the most complete profiles in the whole sample (average $=0.67$ ), followed by managers working in Ekstraklasa company (average $=0.58$ ) and Ekstraklasa 
clubs (average $=0.58$ ). A similar conclusion may be drawn regarding network embeddedness. In contrast, the highest results in activity are shown not only by managers from PZPN, but also from clubs from 2nd-5th divisions (with lower results registered by managers from Ekstraklasa company, and Ekstraklasa clubs). Managers from regional football associations and football academies have the lowest results in all aspects.

Table 3. Indexes - correlation with workplace

\begin{tabular}{|c|c|c|c|c|c|c|c|c|c|}
\hline INDEX & $\begin{array}{l}\vec{\ll} \\
\stackrel{5}{\circ}\end{array}$ & $\frac{Z}{N}$ & 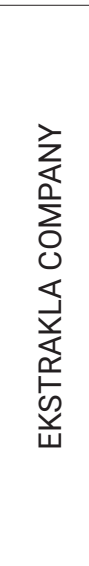 & 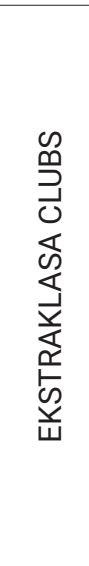 & 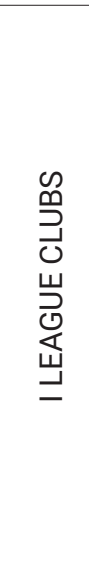 & 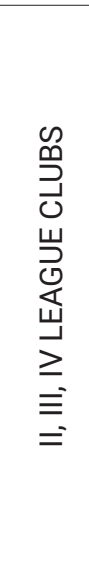 & $\begin{array}{l}z \\
\text { Zn } \\
\mathbf{N} \\
\mathbf{z} \\
\dot{z} \\
\text { N } \\
0\end{array}$ & 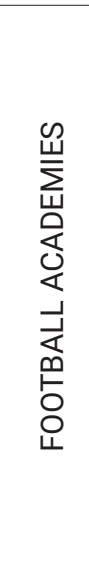 & 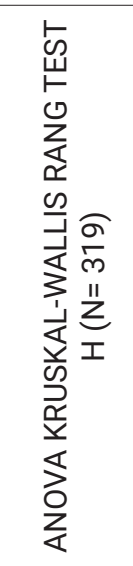 \\
\hline COMPLETNESS & 0.56 & 0.67 & 0.58 & 0.58 & 0.50 & 0.43 & 0.54 & 0.37 & $p=0.00$ \\
\hline ACTIVITY & 0.02 & 0.03 & 0.01 & 0.01 & 0.03 & 0.02 & 0.00 & 0.01 & $p=0.00$ \\
\hline $\begin{array}{c}\text { NETWORK } \\
\text { EMBEDDEDNESS }\end{array}$ & 0.11 & 0.15 & 0.15 & 0.12 & 0.12 & 0.07 & 0.06 & 0.08 & $p=0.00$ \\
\hline ATRACTIVENESS & 0.27 & 0.27 & 0.28 & 0.28 & 0.29 & 0.23 & 0.29 & 0.21 & $p=0.32$ \\
\hline
\end{tabular}

Source: author's own research

The relationship between indexes and managers functions is presented in Table 4. In fact, there is no statistical difference between managers working in marketing vs. managers working in other areas of Polish football with regard to the four indexes.

Table 4. Indexes - differences between marketing and other mangers

\begin{tabular}{|c|c|c|c|c|}
\hline INDEX & TOTAL & $\begin{array}{c}\text { MARKETING } \\
\text { MANAGERS }\end{array}$ & $\begin{array}{c}\text { OTHER } \\
\text { MANAGERS }\end{array}$ & $\begin{array}{c}\text { MANN } \\
\text { - WHITEY U TEST }\end{array}$ \\
\hline COMPLETNESS & 0.56 & 0.57 & 0.55 & $\mathrm{p}=0.97$ \\
\hline ACTIVITY & 0.02 & 0.03 & 0.01 & $\mathrm{p}=0.54$ \\
\hline $\begin{array}{c}\text { NETWORK } \\
\text { EMBEDDEDNESS }\end{array}$ & 0.11 & 0.11 & 0.12 & $\mathrm{p}=0.49$ \\
\hline ATRACTIVENESS & 0.27 & 0.27 & 0.27 & $\mathrm{p}=0.83$ \\
\hline
\end{tabular}

Source: author's own research

The connection between the length of professional experience and indexes is presented in Table 5. In fact, one may observe this connection only in case of two indexes: network embeddedness and activity (at 10\% level in the latter case) - both increase with the length of the professional experience. 
Table 5. Indexes - correlation with the length of professional experience*

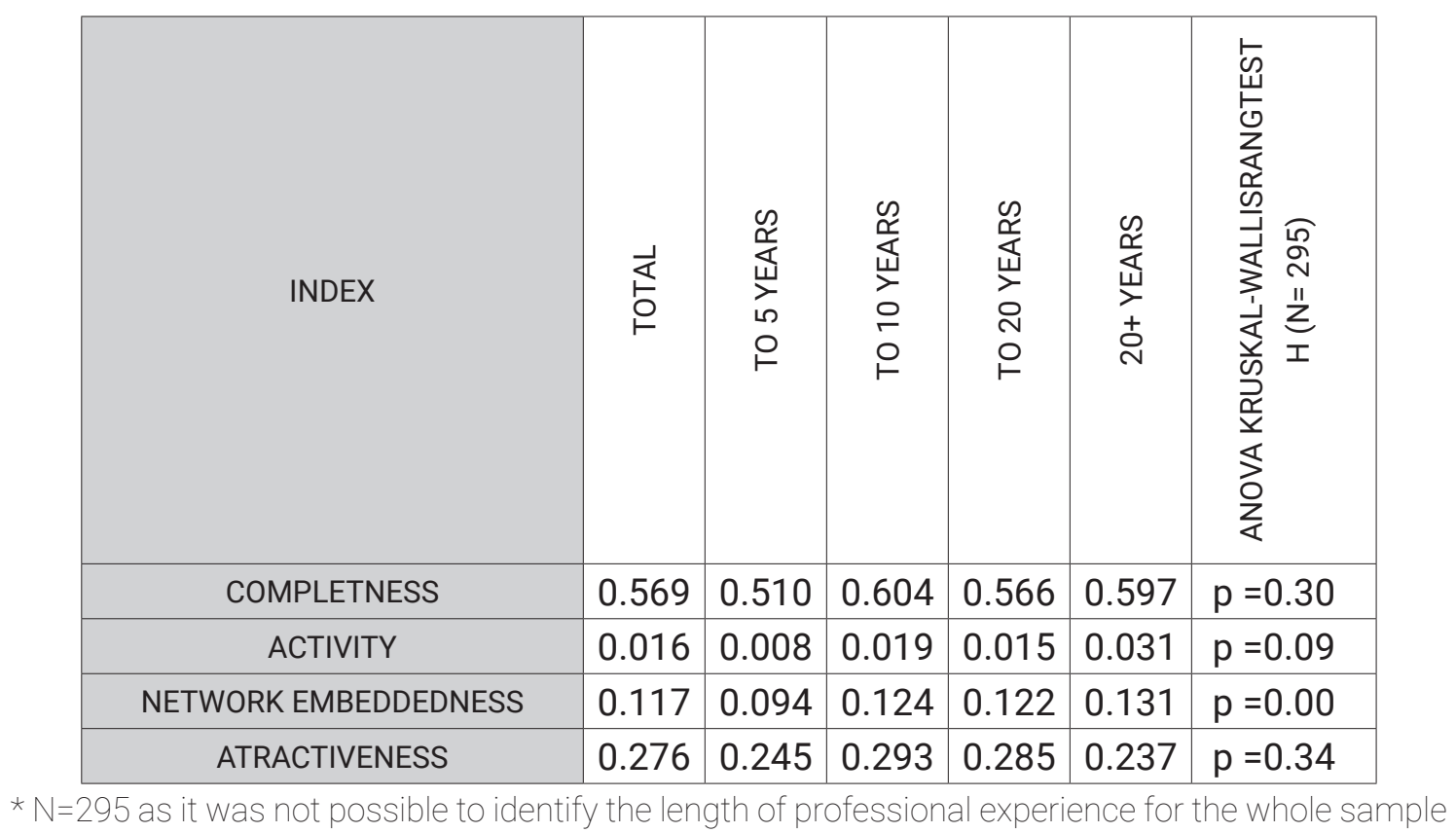

Source: author's own research

\section{DISCUSSION AND CONCLUSIONS}

The goal of the study was to determine the way Polish football managers use Linkedln to create their personal business brand. The main conclusion of the research is that the managers exploit the potential of LinkedIn only in a very limited and mostly static way.

The highest scores are registered in completeness index. It may confirm the research by Lueg\& Nielsen (2015) who claim that LinkedIn, more than XING, encourages users to meticulously fill in information about their professional experience. Secondly, although at the clearly lower level, the attractiveness index appears. Both indexes show a moderate correlation, but also high standard deviations. It can be concluded that although most of the managers complete the main parts of the profile, they do it in a quite basic way. Only the most diligent ones care more about the quality of the information supplied and more advanced personalization of their profile. Neither completeness, nor attractiveness of the profile depends on gender, function, or length of the work experience. Only completeness correlates with the workplace, with the highest scores in the organizations from the top of Polish football (PZPN, followed by Ekstraklasa company, and clubs playing in Ekstraklasa).

The index of network embeddedness of the managers is quite low, as the quasi-totality of them scores not more than 0.3 . This is surprising, as building a network of professional relations is one of the main goals of presence in business social media, and the convenience of Linkedln in this respect is very high. In fact, even though the portal's official philosophy promotes making contact only with people whom a user knows and trusts (because the size of the network is not as important as its quality), Linkedln algorithms recommend members to connect and position profiles with larger contact networks better (Samuel 2018). Similarly, receiving and giving recommendations as well as confirming other members' skills, which are important in building the credibility of the profile, are also underused. Network embeddedness seems to be higher among men than women, among managers working in PZNP and Ekstraklasa company than elsewhere. It rises with the length of professional experience and shows a moderate correlation with the completeness of the profile. 
Network embeddedness may be seen as a prerequisite for activity in Linkedln, as the activity should have some audience. In fact, both indexes show only a low correlation (0.32). The activity index registers clearly the lowest scores among the four indexes with $61 \%$ of managers showing no activity, and following $34 \%$ of them registering only a minimum activity. The cases of regular activity are very rare. Most of the profiles of the football managers are therefore static, serving more as virtual resume, than a tool to build a professional brand. A very similar conclusion was drawn by (Deszczyński 2018) who found that all profiles of Polish export managers were static. In fact, it turns out that many users start or update their profile, and eventually make some activities in business social media in the periods of looking for a new job, and they let the profile inactive once the job found (Roulin, N., Bangerter 2013). Activity rises with the length of professional experience and is higher in PZPN and the second division clubs than elsewhere.

In general, it can be found out that managers working in PZPN score the most in completeness, network embeddedness, and activity. It is coherent with the image of PZPN being the most professionalized football organization in Poland. It is in this organization that most of the innovations in management and marketing activities (social media included) start in Polish football. Moreover, the professional self-presentation in LinkedIn is linked more to the workplace than to the function held in the organization, as the marketing managers do not score better than other managers in any of the researched dimensions. On the other hand, it improves with the length of professional experience. The former result is somehow different than in the study by Evans (2017) who found that people with extensive experience may have difficulty to adapt to modern technological solutions and to run a professional profile. Also in contrast to some studies finding gender differences in self-presentation in social media (Tifferet and Vilnai-yavetz 2018), in this study, only a slight difference in network embeddedness between men and women is found.

The most important practical implication of the study for the managers is the indication, that if a managerial job in PZPN is seen as a professional success in Polish football, an aspiring person should create their virtual brand as the managers from PZPN do - i.e. carrying not only about completeness of the Linkedln profile, but also using the platform to create and share professional content in a dense football network. It will not only provide proof of personal professionalism but may also act as a self-fulfilling prophecy. Even more so as it is not difficult to stand out given a generally low activity and profile attractiveness of most of the managers.

In a broader practical perspective, the results of the study may help effectively build a personal brand in a business social network, also for managers working outside the sport industry. Moreover, the results may be valuable for companies paying attention to their brand presentation in Linkedln through their employers' profiles and activities.

The methodological innovativeness of the study aims to provide the indexes that may serve in a multidimensional evaluation of a self-presentation in a social business network. Further research should verify their application to other professions, also in an international context.

\section{References:}

ANABO, I. F., \&ALBIZURI, I. E. (2017), Linkedln comolnstrumento para la Evaluación de ProgramasdeEducación. Revista de Educación a Distancia, 53(8).

BANERJI, D., \& REIMER, T. (2019), Startup founders and their Linkedln connections: Are well-connected entrepreneurs more successful?,Computers in Human Behavior, 90, 46-52.

BARUFFALDI, S. H., DI MAIO, G., \&LANDONI, P. (2017), Determinants of PhD holders' use of social networking sites: An analysis based on Linkedln, Research Policy, 46(4), 740-750.

CASE, T. L., GARDINER, A., RUTNER, P., \& DYER, J. N. (2012), A linkedin analysis of career paths of informa- 
tion systems alumni,Journal of the Southern Association for Information System, 1(1), 1.

CHIANG, J. K. H., \&SUEN, H. Y. (2015), Self-presentation and hiring recommendations in online communities: Lessons from Linkedln,Computers in Human Behavior, 48, 516-524.

CHO, S. E. (2010), Cross-cultural comparison of Korean and American social network sites: exploring cultural differences in social relationships and self-presentation, Rutgers University-Graduate School-New Brunswick.

CONLON, J., TAYLOR, A., ASHRUFF, P., \& BIRD, L. (2017), Linkedln Groups: Building a community to create real connections to benefit students and alumni in Fashion and Textiles. University of Huddersfield.

COOPER, B., \&NAATUS, M. K. (2016), Linkedln as a Learning Tool in Business Education. American Journal of Business Education, 7(4), 299-306.

DESZCZYŃSKI, B. (2017), Nawiązywanie relacji biznesowych z wykorzystaniem mediów społecznościowych aktywność polskich menedżerów eksportu w serwisach Linedln i GoldenLine,Marketing i Rynek, 9, 58-67.

DUFFY, B. E., PRUCHNIEWSKA, U., SCOLERE, L. (2017), Platform-specific self-branding: Imagined affordances of the social media ecology, Proceedings of the 8th International Conference on Social Media \& Society, 5.

ECLEO, J. J., \&GALIDO, A. (2017), Surveying Linkedln Profiles of Data Scientists: The Case of the Philippines. Procedia, Computer Science, 124, 53-60.

EVANS, J. R. (2017), A strategic approach to self-brandin,Journal of Global Scholars of Marketing Science, 27(4), 270-311.

GEYIK, S. C., GUO, Q., HU, B., OZCAGLAR, C., THAKKAR, K., WU, X., \&KENTHAPADI, K, (2018), Talent Search and Recommendation Systems at Linkedln: Practical Challenges and Lessons Learned, The 41st International ACM SIGIR Conference on Research \& Development in Information Retrieval, 1353-1354.

GUILLORY, J., \& HANCOCK, J. T. (2012), The effect of Linkedin on deception in resumes. Cyberpsychology, Behavior, and Social Networking, 15(3), 135-140.

HEMPEL, J. (2010), How Linkedln will fire up your career, Fortune, 4(12), 2010.

KIM, D., KIM, J. H., \& NAM, Y. (2014), How does industry use social networking sites? An analysis of corporate dialogic uses of Facebook, Twitter, YouTube, and Linkedln by industry type, Quality \& Quantity, 48(5), 2605-2614.

LUEG, K., \& NIELSEN, C. (2015), Impression management as symbolic capital: An intercultural comparison of presentations by CEOs on social network sites, Communication \& Language at Work, 4(4), 88-120.

LINKEDIN (2019). About LinkedIn.[online: 28 April 2019], www.about.linkedin.com

LOPS, P., DE GEMMIS, M., SEMERARO, G., NARDUCCI, F., MUSTO, C. (2011). Leveraging the linkedin social network data for extracting content-based user profiles,Proceedings of the fifth ACM conference on Recommender systems, 293-296.

MORGAN, M. (2011), Personal branding: Create your value proposition. Strategic Finance, 93(2), 13.

Niedźwiedziński, M., Klepacz, H., \& Szymańska, K. (2016), Budowanie marki osobistej w mediach społecznościowych, Marketing i Zarządzanie, (4 (45)), 339-349.

PAPACHARISSI, Z. (2009), The virtual geographies of social networks: a comparative analysis of Facebook, Linkedln and AsmallWorld. New media \& society, 11(1-2), 199-220.

RAMANATH, R., INAN, H., POLATKAN, G., HU, B., GUO, Q., OZCAGLAR, C., GEYIK, S. C. (2018,), Towards Deep and Representation Learning for Talent Search at Linkedln,Proceedings of the 27th ACM International Conference on Information and Knowledge Management.

ROULIN, N., BANGERTER, A. (2013), Social networking websites in personnel selection: A signaling perspective on recruiters' and applicants' perceptions, Journal of Personnel Psychology, 12(3), 143-151.

RUI, J. R. (2018), Objective evaluation or collective self-presentation: What people expect of Linkedln recommendations. Computers in Human Behavior, 89, 121-128.

RUI, J., \&STEFANONE, M. A. (2013), Strategic self-presentation online: A cross-cultural study, Computers in Human Behavior, 29(1), 110-118.

SAINT-JACQUES, G., VARSHNEY, M., SIMPSON, J., \&XU, Y. (2019), Using Ego-Clusters to Measure Network Effects at Linkedln, 1-23.

SAMUEL, A. (2018), Im więcej znajomych mamy na Linkedln, tym mniejsza jest jego skuteczność,[online: 1 September 2018], https://www.hbrp.pl/b/im-wiecej-znajomych-mamy-na-linkedin-tym-mniejsza-jest-jego-skutecznosc/18RPH083H

SCHWÄMMLEIN, E., \&WODZICKI, K. (2012), What to tell about me? Self-presentation in online communities, Journal of Computer-Mediated Communication, 17(4), 387-407.

SIEVERS, K., WODZICKI, K., ABERLE, I., KECKEISEN, M., \& CRESS, U. (2015), Self-presentation in profession- 
al networks: More than just window dressing,Computers in Human Behavior, 50, 25-30.

SZNAJDER, A. (2007), Charakterystyka rynku sportu profesjonalnego. Gospodarka Narodowa, (10). [online: 24 April 2019] http://gospodarkanarodowa.sgh.waw.pl/p/gospodarka_narodowa_2007_10_03.pdf

TIFFERET, S., \&VILNAI-YAVETZ, I. (2018), Computers in Human Behavior Self-presentation in Linkedln portraits : Common features, gender, and occupational differences,Computers in Human Behavior, 80, 33-48.

TOMA, C. L., \& HANCOCK, J. T. (2010), Looks and Lies: The Role of Physical Attractiveness in Online Dating Self-Presentation and Deception,Communication Research, 37(3), 335-351.

UTZ, S. (2016). Is Linkedln making you more successful? The informational benefits derived from public social media,New Media and Society, 18 (11), 2685-2702.

VAN DE VEN, N., BOGAERT, A., SERLIE, A., BRANDT, M. J., \&DENISSEN, J. J. A. (2017), Personality perception based on Linkedln profiles, Journal of Managerial Psychology,32(6), 418-429.

WASYLKOWSKA, M. (2011), Rola menedżera sportowego w zarządzaniu klubami sportowymi, Zeszyty Naukowe Uniwersytetu Szczecińskiego. Finanse, RynkiFinansowe, Ubezpieczenia, (46), 283-293.

ZIDE, J., ELMAN, B., \&SHAHANI-DENNING, C. (2014), Linkedin and recruitment: How profiles differ across occupations, Employee Relations, 36(5), 583-604. 